\title{
MED1 wt Allele
}

National Cancer Institute

\section{Source}

National Cancer Institute. MED1 wt Allele. NCI Thesaurus. Code C52149.

Human MED1 wild-type allele is located within 17q12-q21 and is approximately $45 \mathrm{~kb}$ in length. This allele, which encodes mediator of RNA polymerase II transcription subunit 1 protein, is involved in both apoptosis and adipogenesis. Expression of the wild-type allele is required for Sp1 mediated transcription. 